Politics in everyday Kenyan street-life: the people's parliament in Mombasa, Kenya

Stephanie Diepeveen ${ }^{*}$

Department of Politics and International Studies, University of Cambridge, Cambridge, UK

Correspondence details: Jesus College, Cambridge CB5 8BL, Phone Number: +44

7596023167, Email: snd31@cam.ac.uk

The Version of Record of this manuscript is published and available in the Journal of Eastern African Studies (June 2016) via www.tandfonline.com http://dx.doi.org/10.1080/17531055.2016.1187806

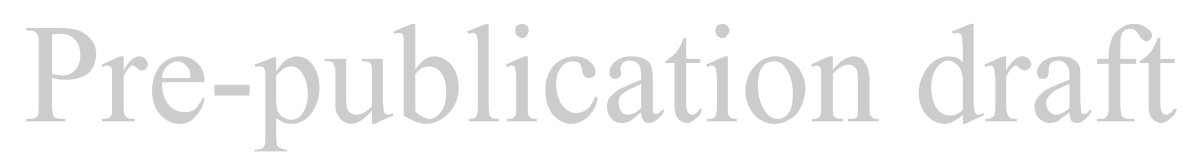

\footnotetext{
*Corresponding author. Email: snd31@cam.ac.uk
} 


\section{Politics in everyday Kenyan street-life: the people's parliament in Mombasa, Kenya}

The presence of politics in everyday experiences is not new to the study of politics in Africa, located in popular arts, culture and dialogue. Yet, most often, attention to political possibilities in the everyday appears preoccupied with their relationship to rule and authority, making it difficult to imagine political significance outside of an influence on forms of dominance. Hannah Arendt's early political thought provides an alternative way to imagine politics in everyday publics, separating politics from rule and locating it in public speech and action. Drawing on Arendt's ideas around political significance of publics, this paper examines the nature and scope of political possibilities of a street parliament in Mombasa, Kenya. It reveals how possibilities for Arendtian political action are present in informal practices of public discussion, which are both contingent upon and compromised by competing interests, including elite and partisan competition.

Keywords: Street parliaments, public sphere, Kenya, Hannah Arendt

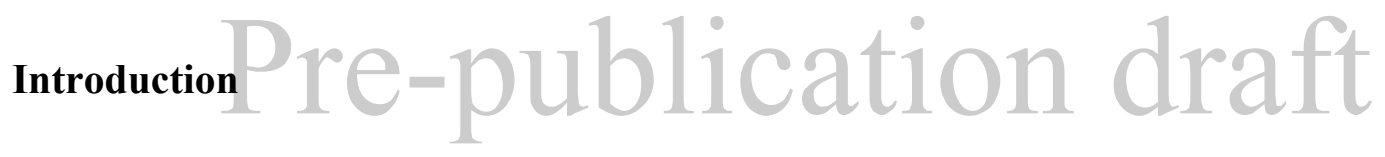

Throughout Mombasa, men routinely gather at street corners, bus stages and around shoe polishers to consider issues of shared concern, often partisan politics but sometimes religion, business and culture. These informal gatherings, also known as street or people's parliaments, form part of the city's street life. They are not formally convened, yet they still form with a degree of regularity as people move through the streets from day to day. They are populated almost exclusively by men, from those in their late 20 s to a few in their 60 s. Participants are diverse in their employment status, including those who are unemployed, retired and also those who work in the area and come during breaks in their workday. While each gathering tends to be dominated by specific partisan allegiances, there are participants from diverse ethnic groups and places of origin in Kenya, and Christians and Muslims. There is a particular animation to the street parliaments. Participants are motivated to attend by interest in national and local politics. They convene without financial incentive or formal 
organisation in a public or semi-public space in the city. They are a place of political debate that forms from the bottom-up.

Amongst gatherings dotted throughout the city, the people's parliament that forms just outside of the abandoned Polana hotel in downtown Mombasa is the most well-known to politicians, mainstream media and more widely in the city. Men gather at this street corner on weekdays. Early in the afternoon, a few men will be seated on a bench leaning against the wall of the hotel where they are slightly shielded from the noise, traffic and congestion of the centre of town. As the day passes, more people congregate, one might carry a newspaper, another might be reading on his mobile phone. Multiple, ad hoc conversations begin, most often in Swahili, interspersed with some English. As conversations ensue, someone usually begins to dominate the discussion, projecting his voice and explaining his take on a current news story to those who are gathered. An entertaining address attracts more participants. The gathering grows to 40-50 participants. As more gather and the discussion becomes increasingly heated, someone attempts to control the debate and claims the role of speaker, fielding and directing contributions. Individuals refer to each other as "honourable," explicitly invoking the idea of a parliament, in which they are all members. A few participants override others' contributions, even interrupting at times. Also, not all comments are received as equally valid. Someone might make a comment that others interpret to be sympathetic to the Kenyan president. Another cries out, "That is out of order," questioning the basis for the claim. Discussion continues. At another point, heckling might erupt, incited by a statement that appears critical of another prominent national politician. The acting speaker of the gathering calls out, "Order in the house! Order in the house!" He admonishes the hecklers, and reaffirms the debate as open and inclusive to any comment that appears informed. The evening progresses and men disperse for the night. They leave a few rickety 


\section{S. Diepeveen}

benches propped up against a wall, a physical remnant of the gathering. The ideas are carried beyond the place and gathering through the memory of the participants.

The content, identity and public nature of these street parliaments in Mombasa, such as the one outside the Polana hotel, points to phenomena of wider interest in political scholarship on Africa, which considers the presence of politics in everyday life. This literature draws attention to everyday discursive practices as sites for political subjectification, the exercise of authority and its resistance. ${ }^{\mathrm{i}}$ Taking the case of the informal street parliament in Mombasa, I suggest there is another way we can identify the political salience of informal and ordinary public discussion, which identifies political possibility in the act of public speech itself, irrespective of its influence on forms of authority. Hannah Arendt's understanding of political action and publics provides valuable insights into the intrinsic possibilities of everyday publics. She identifies political significance in the creation of a common world through collective speech and action, as opposed to the exercise or contestation of rule. By drawing on Arendt's understanding of politics, I will argue that the ordinary and uncertain nature of the street parliament in Mombasa reveals an irrepressible potential for new and different shared imaginaries to arise through ongoing public speech and action.

\section{Publics in Africa}

Academic interest in the political significance of everyday experiences in Africa grew in the 1980s and 1990s alongside recognition that opportunities for public participation appeared restricted across the continent. With restricted formal space for citizen participation in political decision-making, scholars searched for signs of limits to state dominance in more informal, non-political activities. Popular music, literature, art forms and theatre entered into the study of politics. ${ }^{\text {ii }}$ As shared forms of expression, popular arts were potential platforms 
through which people could contest the dominant political order by circulating alternative ideas of authority, difference and inequality. ${ }^{\text {iii }}$ Ellis' work on "Radio Trottier" or pavement radio in West Africa locates the contestation of authority in informal discussion in the streets. ${ }^{\text {iv }}$ More recent studies identify similar possibilities across different media, from interactive radio broadcasts ${ }^{\mathrm{v}}$ to rumours circulating through mobile phones. ${ }^{\mathrm{vi}}$ There is an interest in avoiding normative tendencies of studies of everyday politics and the public sphere, and taking a genealogical and ethnographic approach to examining spaces for informal public discussion in Africa. ${ }^{\text {vii }}$ This scholarship affirms the importance of looking at politics outside of the state. It draws attention to particular ways that everyday practices are intertwined with the exercise of authority, and past expectations, inequalities and forms of exclusion.

By focusing on the ways that dominant shared imaginaries are constructed through mundane public discussion, it becomes difficult to imagine the political significance of informal publics outside the exercise and limitations of dominance and rule. By distinguishing politics from "rule" and "force," Hannah Arendt provides an alternative framework from which to identify politics in the everyday, contrasting and complementing studies that unpack dynamics of dominance and resistance. Arendt's ideas about the nature and significance of a public realm contrast with the influential work of Jürgen Habermas, whose study of the public sphere is tied to a concern for democratic legitimacy. ${ }^{\text {vii }}$ Concerning politics in Africa, the invocation of Habermas' study of the public sphere has often led the investigation of relationships between empirically-grounded notions of the public sphere, and the state and formal authorities. ${ }^{\mathrm{ix}}$ In a different way, Arendt locates political action in the very act of people speaking and acting together. She shifts attention from a concern with rule and power over others to political power in shared action and dialogue. ${ }^{\mathrm{x}}$ The power of political action lies in creative possibilities that arise from interactions amongst equal and 


\section{S. Diepeveen}

distinctive individuals. As Arendt suggests in The Human Condition, "While strength is the natural quality of an individual seen in isolation, power springs up between men when they act together and vanishes the moment they disperse."xi Politics for Arendt concerns what exists between people as they speak and act as part of a community of strangers that extends over generations. Public interactions both require and produce a "common world" that sits inbetween:

"[W]herever human beings come together - be it in private or socially, be it in public or politically - a space is generated that simultaneously gathers them into it and separates them from one another. Every such space has its own structure that changes over time and reveals itself in a private context as custom, in a social context as conversation, and in a public context as laws, constitutions, statutes, and the like. Wherever people come together, the world thrusts itself between them, and it is in this in-between space that all human affairs are conducted."xii

As people act and speak together, the possibility arises for their interactions to reshape "the way in which people recognize themselves and their commonality."xiii Public discussion creates a common world in and across people's interactions, the basis of intersubjectivity. By locating politics in the creation of this "common world," Arendt provides a way to conceptualise political power irrespective of authority or formal structures. Politics exists in moments of concerted action, when individuals disclose who they are, and realise shared notions of difference and commonality. Not every interaction that occurs in public exhibits the creative power to reshape a common world. Arendt suggests particular conditions underpin the possibility for public activity capable of recreating a "common world." First, they are rooted in publicity, in which interactions extend to an indefinite community over generations, and are aimed at shared understanding and not what is intimate or idiosyncratic. Second, discussion requires the acknowledgment of plurality, in other words, the freedom to appear in different ways, and equality to have these differences 
recognised. Concrete places might carve out opportunities for public and plural discussion, freeing people to express themselves in different ways. However, they can also constrain the possibilities for political action. The presence of violence can silence people, rendering them unable to disclose who they are freely. A preoccupation with necessity can replace the unpredictability of human speech with the predictability of processes designed to maintain life. ${ }^{\text {xiv }}$

Working from Arendt's The Human Condition, I adopt an approach that locates politics in everyday public dialogue between plural and equal (potential) strangers. This perspective does not deny the presence of inequalities and forms of dominance in public life. Such dynamics are part of the world in which people exist with one another, but from this perspective, they are not the essence of politics. Politics in everyday experiences concerns the potential to reshape a common world through people's interactions, and becomes possible through conditions of publicity and plurality.

\section{Public dialogue in Mombasa}

The spaces for daily public discussion in Mombasa reflect its diverse and rich history as a Swahili urban centre and port city on the Eastern African coast. Partially, public life in Mombasa is constructed through the winding streets, taarab music, infrastructure and baraza of Swahili culture. ${ }^{\mathrm{xv}}$ Along the Swahili coast, men would gather as baraza in semi- and semipublic spaces to discuss issues of shared concern from philosophy, religion to politics, the term baraza indicating the benches at the front of Swahili houses. Describing the baraza from Stonetown, Zanzibar, Loimeier (2009) suggests, "Due to the semi-public, semi-formal, and semi-open character of the baraza, the baraza escapes efforts of categorization: baraza may, in fact, be described to be 'semi' in many respects."xvi Kresse (2007) points to the multiplicity of such public and semi-public places in Swahili culture for men to speak about 


\section{S. Diepeveen}

issues of shared concern, often with the rhythm of afternoon and evening prayers. ${ }^{\text {xvii }}$ Women would meet separately as was feasible within their responsibilities, often more casual and irregular. ${ }^{\text {xviii }}$ In Mombasa, over time, particularly since the coast was established as a British protectorate in 1895, Kresse (2007) suggests baraza became more informal meeting points, demarcated by mutual trust and privacy. ${ }^{\text {xix }}$ While baraza has also come to connote a more formalised, staged gathering by political leaders and the government administration in postcolonial Kenya, ${ }^{\mathrm{xx}}$ its conceptual and historical roots are also tied to the baraza as informal, semi-public gatherings among Swahili. In Mombasa, the centre of Swahili life and culture is in Old Town on Mombasa Island, reinforced visually and audibly through architecture and sound. Arabic and Swahili texts are projected from rooftop speakers, radios and computer speakers across mosques, shops and homes. Sermons, songs and recitations from the Quran spread out to the narrow streets and densely packed Swahili-style buildings, constructing a public Swahili-Islamic identity through sound in public and semi-public spaces. $^{\text {xxi }}$

Swahili culture indicates only part of public life in Mombasa. As the city has developed around its port as well as tourism, Mombasa has become ethnically and religiously diverse. A poll by Ipsos Public Affairs in October 2013 indicates one-third of residents from ethnic groups are estimated to originate from outside of the coastal region, and religiously, Mombasa appears to be comprised of $40 \%$ Muslims and $60 \%$ Christians. ${ }^{\text {xxii }}$ The presence and position of people from other areas of Mombasa is reflected in popular culture. Work by Eisenberg (2012) on hip-hop among youth in Mombasa in the 1990s illustrates how a popular song Mombasani became a "theme" among struggling youth artists in Mombasa, conjuring a notion of being in Mombasa but not being of or a subject of Mombasa and the Swahili coast. Through hip hop music, artists navigated multiple identities within the city through music, as coastal, Kenyan and global. ${ }^{\text {xxiii }}$ Fieldwork conducted in 2013-2014 in Mombasa drew 
attention to further informal street gatherings, distinct from the Swahili baraza and occupied by both wapwani and wabara (coastal and upcountry people, respectively, Kiswahili). These gatherings would refer to themselves as bunge (parliament, Kiswahili), claiming the name of a parliament and demarcating a public or semi-public space in the streets and at bus stages for public discussion, mainly concerning county and national politics. ${ }^{\text {xxiv }}$ The notion of bunge in Mombasa has resonance and legacies outside the coastal region, from more formally organised bunge la mwananchi gathering throughout Nairobi, most famously at Jeevanjee Gardens, to more informal bunge in cities such as Kisumu, Eldoret and Nakuru. ${ }^{\mathrm{xxv}}$

Within the array of places for informal and daily public dialogue in Mombasa, this paper focuses on the political possibilities of the street or people's parliaments, of interest given their diversity, regularity and multiplicity throughout the city. Similar to the approach to everyday politics encouraged in Banégas, Brisset-Foucault and Cutulo's (2012) Special Issue in Politique Africaine on people's parliaments in Africa, I adopt an ethnographic approach to the study of the nature and significance of everyday publics, interrogating the relationship between the context, practices and participants' experiences. This includes sociolinguistic analysis of the discussion and participants' depiction of the gatherings. It is based on eight months of observation and interview-based fieldwork conducted in Mombasa between September 2013 and September 2014. Research includes approximately 130 observations at bunge, youth parliaments and civil society forums, and 193 interviews of varying degrees of formality with bunge participants, civil society activists, political aspirants, and members of the county and national government. Interviews included questions about individuals' political engagement over time at bunge, with government and more widely. All interviews were conducted face-to-face by the author and were anonymised. Most were conducted primarily in English, with some Swahili words and phrases. A local 
translator assisted with interviews that were conducted predominantly in Swahili. The majority of interviews were recorded and transcribed with the permission of the interviewees.

This study reflects a particular moment in Mombasa when there was growing attention to citizen-state relations, and constraints on freedom of association and movements, linked to rising insecurity and securitisation efforts. ${ }^{\text {xxvi }}$ In addition to the terrorist attack on Westgate Mall in Nairobi in September 2013, in Mombasa, insecurity rose through targeted killings of prominent Muslim clerics in Mombasa, an attack on a Likoni church in March 2014 and grenade attacks on a Mombasa hotel and bus station in May 2014. Constricting the freedom of movement and expression were tightening security measures, which included temporary checkpoints at key junctures and the presence of the paramilitary wing of the Kenyan police, the General Service Unit (GSU), patrolling the streets of Mombasa.

\section{The street parliament outside the Polana hotel}

This paper focuses on the nature and possibilities for political action of a well-known and informal bunge that convenes on weekdays in central Mombasa. Among the street parliaments in Mombasa, this gathering would be referred to as the centre of bunge in Mombasa, of which more than a dozen were identified across the city. As introduced at the onset of this paper, this bunge materialises just outside of the empty Polana Hotel and is locally known through reference to its location, i.e. Polana. ${ }^{\text {xxvii }}$ There are indications of a temporal and spatial predictability to Polana as a place of public dialogue, echoing the nature and form of bunge elsewhere in Kenya. ${ }^{\text {xxiii }}$ On a daily basis, mostly men pause to consider national and local politics, key political personalities, economics, and social and cultural issues. As one young man at Polana commented,

\footnotetext{
"Polana is just a place where people meet after work. It is not a designated place where people say today we have this agenda on the table, and we will discuss. [It is] a place of convergence, [to] converge and listen and express their views."
} 
Time for public discussion at Polana is carved out from within people's unoccupied time. Those who are unemployed sometimes participate in the gathering from midday to evening; for those who are employed, their participation reflects the rhythm of their workday. People tend to congregate in the afternoons and evenings, passing by during a lunch break or as they finish work. Small business owners stop by when there is a lull in activity at their shop. Those on contract work will come for days at a time, sitting at Polana for most of the day and disappearing for weeks or months when a temporary work contract begins. Another man, who participates in the street parliament at Polana and also near his home in Changamwe constituency, explained that Polana is a place "[to] kill time."xxx More often than not, debate is relaxed, with a few participants sitting and the rest standing around. If the debate becomes heated, someone usually assumes the role of speaker to field who speaks. Debates centre on a few vocal speakers who project their opinions on current affairs to whomever might pass by. On most days, the gathering vacillates between 20 and 60 participants, surpassing more than 100 participants during a period of heightened political tension or when a prominent politician passes by.

At first glance, the identification of space for open discussion at Polana appears to be firmly grounded in a physical location. As mentioned above, it even draws its name through reference to the hotel where they meet. Yet, any attempt to clarify its physical boundaries reveals the intangibility and elusiveness of Polana as a place. Narratives of how Polana began do not refer to one location, but to the people who congregated and the content of their discussion. Polana is described as first beginning to meet during de facto one party rule in the 1990s as a gathering of individuals who were unhappy with the dominance and coercion of the government of Daniel arap Moi, and a lack of space for opposition voices inside government and in public. Early days were marked by tales of violent police repression and incarceration. The 2002 elections brought about a transition from the incumbent party to a 


\section{S. Diepeveen}

new government, formed by a coalition of opposition parties. Generally, this period of time was marked by increased freedom of association and speech in Kenya. Alongside, participants remembered Polana as increasingly vibrant, providing possibilities for people to air and listen to divergent viewpoints. ${ }^{\text {xxi }}$

Notions of Polana as a unified gathering appear short lived as violence directly enveloped the physical space occupied by the bunge. In 2007, the Kenyan general elections were marked by allegations of electoral rigging against the Orange Democratic Movement (ODM), a political party opposing the incumbent regime and led by presidential candidate, Raila Odinga. It was followed by post-election violence across multiple sides. At Polana, confrontations with the police re-emerged. Amidst wider unrest, Polana is recalled to have split, with divisions manifesting spatially. Divisions reflected and constituted tensions around political party, language, notions of ethnicity and place of origin. ${ }^{\text {xxii }}$ Participants describe how they increasingly would meet in smaller groupings, organised around ethnicity, language or political party. Explanations as to why these divisions occurred emerge around two themes. The first identifies the destabilising effect of experiences of violence and disillusionment. The second explanation refers to a view of Polana as associated with the national opposition. One local secretary for the ODM party suggested that government supporters separated themselves from the main gathering at Polana following recent elections due to their minority status in Mombasa, given overwhelming support by the Mombasa electorate for opposition political parties. They looked for a place where they might "console themselves because they are [in the] minority."xxxiii

Spatial divisions at Polana, and the subjectivities that constitute them, are continually evolving. These divisions do not only reflect wider political contest, but also the more immediate concerns and subjectivities of those present. In early 2014, a Muslim scholar chastised participants for speaking in vernacular (Dhuluo). He asserted strongly that Polana is 
national, and debate must proceed in languages accessible to all Kenyans, i.e. Swahili and English. Following this, one Luo mzee (elder, older man, Kiswahili) shifted to sit a few metres away. Some participants identifying as Luo began to congregate around him, conversing in their vernacular. In subsequent days, public address in the Dhuluo vernacular occurred simultaneously around this mzee just a few metres away. Individuals could move between these spatial divisions. Participants with the language skills could transgress Swahili, English and vernacular debates, while those interested in different political parties and their perspectives would move between government- and opposition- dominated areas.

Instances of physical violence in the streets also temporarily disperse the gathering at Polana. The threat posed by al-Shabaab and the increasing securitisation of Mombasa heightened awareness of the possibility of violence. Violence has spilled over into the place occupied by the street parliaments through, for example, physical confrontations between protestors and the police following the targeted killings of Muslim clerics. Confrontations take over the streets in the area, closing shops, clearing the streets of vehicles and pedestrians, and dispersing the bunge. People reconvene as they resume their routines once violence subsides.

Amidst these physical disruptions to the gathering, it is difficult to identify the boundaries of the bunge. The place and participants who constitute the gathering are changing, and concurrently the form and limits of gathering are conceptualised in different ways. As memories of its history suggest, Polana is consistently identified with the national opposition. Also, its proceedings mimic the structure of a parliament, forming a parody and alternative to the official Kenyan national parliament. Participants reason that as a parliament, a plurality of people and ideas must be present. An acting moderator could be told to leave, if thought to be biasing the space or preventing plural party positions to be articulated. This plurality is in contrast to the County Assembly of Mombasa at the time of 


\section{S. Diepeveen}

fieldwork (2013-2014), in which all elected and nominated members were ODM. Polana is most lively when there are individuals present who directly challenge the dominant party allegiances and argue in favour of the national government, contradicting its association with political opposition. Still, there remains an underlying resistance to fully accepting different viewpoints. Views that are interpreted as favourable to the national government are met with vocal, strong resistance. While non-dominant positions bring life and diversity to the debate at Polana, they also invoke a public resurgence of a shared identity as a partisan opposition. While anyone can listen, anything cannot be said.

The presence of multiple and opposing group identities at Polana becomes even more visible when considering how individuals are recognised. At one level, people can enter Polana as strangers, listening and speaking equally as anonymous passers-by. Separated from their places and relations of work and residence, each person can be addressed as mheshimiwa (honourable, Kiswahili). A person can listen and speak, without anyone being certain of "who" they are elsewhere. Someone could be part of the high echelons of the organised political parties or unorganised, but vocal "psychofans." "xxxiv Often participants imagine the scope of ideas at Polana to extend through the wider uncertain networks and movements of those directly in attendance. The anonymity of the audience facilitates a sense of a diffuse reach of ideas travelling through the networks of those directly in attendance.

Yet, as people gather from day to day, it appears impossible to maintain an image of those present as anonymous waheshimiwa (honourables, Kiswahili). The creation of new ways of relating to each other through public dialogue is premised upon some pre-existing shared understanding. In addition to being calling mheshimiwa, an individual is recognised by the name of a party or a politician, usually tied to a person's place of origin or ethnic group. Participants tend not to resist these terms of identification. Some even claim particular subject identities as a source of pride. Familiarity surrounds regular participants. Those who 
come from day to day might know little of what people do or where they go when they leave Polana, but through interactions at Polana they gain a vague awareness of people's education, political preferences, employment, religion, ethnicity and place of origin, etc.

On one side, where and how Polana has emerged indicate a sense of consistency and predictability in its place and group identity, which limits the openness of its discussion. Those who pass by expect particular types of people to be present in a defined place, and to speak in certain ways. Polana reveals and mimics established and common-sense ways of interpreting political experience, invoking divisions and inequalities along ethnicity, place of origin, political party and personality. The relations that form between regular participants shape how they address each other and interpret each other's contributions. On the other side, the limits and form of Polana are also elusive. The place of discussion shifts. The proceedings vary in formality. Participants disperse to other places, people and activities. Polana is not a definitive place and gathering - it might appear predictable and established, but it is dynamic and unstable as ideas and people converge and diverge with the rhythm and movement of people through the streets.

\section{The circulation of ideas}

As Polana's daily existence ebbs and flows with the movement of people, it indicates its openness and publicity, but makes any attempt to define its boundaries appear futile. The form and publicity of the gathering, bound up with the constant circulation of people and ideas, makes it perhaps more appropriate to conceptualise Polana as demarcated by boundaries that are internal to wider publics. Therefore, the conditions of Polana as "public" cannot be understood by looking within spatial boundaries, but require attention to how they are constructed through wider movement of ideas and people. 


\section{S. Diepeveen}

The ideas that are raised at Polana are informed by varied and often invisible sources. Those who gather display a desire for information about national and local issues of shared concern. Beyond Polana they seek information from wherever it might be found, including mass media, friends and acquaintances, internet sites and social media, and organisational networks. Most often, they read printed newspapers, copies left and read by the regular clients at shoe cobblers and street-side fundi (tailor, craftsman, Kiswahili) set up in the area. People gather information from television, radio, and through friends, family and acquaintances in Mombasa, Nairobi and elsewhere. Party networks (headquarters to regional), and campaign teams - particularly close advisors and strategists - are also drawn on to construct detailed pictures of current events.

Ideas are publicised at Polana by the people who participate. A news report or public document (often the 2010 Constitution of Kenya) might be mentioned in the public address but often is not seen or heard directly. Periodically, someone will read out a "breaking news" story from their mobile phone, reference a story from a newspaper, or bring documents pertaining to a local news story and use that to inform his contribution. Participants' mobile phones provide access to information almost immediately through social media, texting and calls, accessing information from acquaintances, media houses and political statements from politicians. More often, as sources tend to be removed from the physical gathering, those who are listening are left to assess the contributions based on what was said, the reasoning used, and its coherence with their own experiences and perceptions.

People are drawn to discussion at Polana when uncertainty about partisan and electoral competition is heightened. Interest appears to be sparked by active competition for formal authority. One example when this was particularly acute occurred in response to the disruption of party elections at the ODM delegates' conference at Kasarani stadium, Nairobi on Friday, 28 February 2014. The event was broadcast live on television, its descent into 
chaos visible across Kenya, though its cause and implications were unclear. This event was of particular interest in Mombasa, given the overwhelming popularity of ODM in Mombasa in both the 2007 and 2013 General Elections. By mid-afternoon on the following day, there were already 50-60 men gathered at Polana discussing the previous day's events. Those present were posing questions to one man, who self-identified as a political analyst. A Muslim civic educator was moderating the discussion. A couple of hours later, the moderator had left, but discussion of the elections was ongoing, with approximately 40 men present.

In the few days after the ODM party elections, conversations about the event and its aftermath continued to materialise at bunge throughout town, from Polana to smaller groups gathered around shoe cobblers and polishers. The following Monday, one key informant from Polana took me to various shoe cobblers' stations scattered around the central business district. Going from street to street, shoe polisher to shoe polisher, he sought out individuals he knew to be connected to ODM party networks or who might have been present at the ODM elections in Kasarani stadium. Through these conversations, a story was constructed about events since the elections, which suggested an interim committee was being formed of six persons who represented both factions to manage the party for three months. This narrative emerged alongside ongoing proceedings in Nairobi, specifically closed-door meetings chaired by the party leader that same day and announced in a press conference in the early afternoon. ${ }^{\text {xxx }}$ Ideas about the meetings circulated almost simultaneously with the progression of events in Nairobi, revealing close linkages between people passing through the bunge and national politics. Specific pathways of information remained largely invisible, but emerging narratives were not dissimilar to what was published in the broadcast media. ${ }^{\mathrm{xxxvi}}$ Access to ideas and people around the ODM delegates' conference reveals the potential for immediate and privileged access to information amongst those who spend their leisure time in these informal places of debate. 


\section{S. Diepeveen}

Still, while participation in the street parliament might indicate a privileged position to know about current affairs and high politics, the validity of the information being publicised through the street parliament remains questionable. Ideas shared in the informal gathering are open to interpretation and refute. The informality and interconnectedness of people and ideas at Polana not only allow for novel ideas to be raised, but also bring the possibility of propaganda and rumour. As a result, ideas that are shared at Polana are not necessarily accepted or internalised by those who participate. They are difficult to substantiate. For some, much of what is said at Polana is written off as propaganda. The entanglement of truth with propaganda is not specific to Polana. Most interviewees indicated truth cannot be separated from propaganda in politics in Kenya. As one male street-side fundi (craftsman, tailor, Kiswahili), around which others gather to discuss politics, commented, "you know politics, you must add something."xxxvii Another man, a close confidant of an appointed member of the county government, suggested, "You know, politics, first, you need to speak the truth inside and then you need to form a strong propaganda.'

Suspicion that ideas and viewpoints shared at Polana might be propaganda shifts participants' attention away from the gathering, towards other experiences and relations in order to interpret what was shared. Participants at the street parliament make sense of what is shared by referring to information from a variety of sources, from mass media to personal friends and acquaintances. Some interviewees at Polana suggested individual participation in public debate can improve a person's ability to identify propaganda. When people have information they can build a defence against being cheated or deceived. ${ }^{\text {xxxix }}$ What signifiers are present through which to assess the reliability of the individual and the source of information become important. Again, some read from documents, news articles (print or on the phone) and the constitution to demonstrate reliability of information. A few individuals emerge as key "opinion formers," ${ }^{, x l}$ confidently asserting their position to interpret political 
events. Their claims to authority in the gathering differ, drawing on their age and experience, knowledge of the constitution, or their professions, such as a teacher or journalist. These individuals recognise each other's claims to authority. They direct comments to one another and give each other time to speak. Nevertheless, even the comments of the "opinion formers" are refutable; an illusion of stability is evident as they continue to repeat their claims and opinions from day to day. The openness and diversity of ideas shared thus present a challenge for participants in how to make sense of what they observe. Not only do they result in multiple ways of interpreting ideas amongst participants, but also any idea or interpretation of the discussion is precarious.

\section{The emergence of competing imaginaries}

The elusive boundaries and contestability of information shared at Polana provide scope for people to imagine one another, and Polana itself, in diverse ways. Recalling Arendt, the fact that people are able to imagine the gathering differently indicates its significance. The potential value of public dialogue is not necessarily in its impacts on rule and authority, but in the opportunity to create new and shared forms of knowledge. The openness of ideas and how they might be interpreted through the discussion at Polana indicates scope for new and shared ideas to arise through its discussion. This raises a question about how people are responding to this possibility, in other words, how Polana is actually being imagined and positioned within participants' experiences of public life in Mombasa.

Because Polana is dynamic and indefinite, it is futile to try to grasp the entirety of who gathers and how they perceive the gathering. Observing and interviewing around Polana over time, however, indicates the presence (or not) of different and common ways that Polana features within participants' perceptions of themselves as part of a wider community. For some, public speech is the foundation for their political involvement. These participants identify their influence on authority in public speech, attempting to persuade others of their 


\section{S. Diepeveen}

opinions at places such as Polana. ${ }^{x l i}$ One man, who has participated at Polana since coming to Mombasa from Eldoret in the 1990s, commented,

\footnotetext{
"We want [to] exercise our views so that we can understand each other so well [about] what are the difficulties we are facing, and that is why sometimes I find myself being here: to gather different views of others." "xlii
}

Another participant, a pastor who passes through Polana from time to time, suggested, "I feel it is also a good place to know what the world is seeing." they imagine they are contributing to the formation of public opinion more widely in Mombasa and Kenya. Such participants at Polana appear to adopt an identity as "opinion formers," carrying ideas from Polana to their homes, deriving authority to speak about politics by virtue of their attendance at Polana. ${ }^{\text {xliv }}$ As one participant at Polana, a campaigner for the Wiper Democratic Movement, asserted as he reflected on Polana's significance, "you become kind of the ... informer, then you become the opinion leader. Now, what you bring to them at any given time is taken like a kind of gospel truth." $x l v$ They contrast themselves to people who lack the capacity or time to move into the centre of town, confined to more residential or remote areas of Mombasa where, as this same participant commented, "people don't have a choice. They have never made a choice. They don't have an ideology so they are easily convinced by the person who has brought them the new [idea]."xlvi

For other participants, Polana is peripheral to how they position themselves within public life. Some recall the struggle for multi-party democracy and a transition from a KANU-dominated government in the 1990s. They were present and involved during key moments of struggle in national memory, for example one indicating physical scars that remained from his presence at confrontations at Kamukunji grounds in $1990 .^{\text {xlvii }}$ Others explain their support for opposition politicians and their parties in the 1992 and 1997 elections. ${ }^{\text {xlviii }}$ More often, participants at Polana date their involvement in political contest to 
recent elections, often the 2002 general elections, 2004 by-elections or the constitutional referendum in 2005. Some tell of how they became involved as part of a friend or relative's campaigns. ${ }^{\text {xlix }}$ Others were integrated into organised campaigns for county- and nationallevel politicians as campaigners and campaign coordinators. ${ }^{1}$ Finally, some directly aspired to be elected to political office, a few having unsuccessfully contested in past elections. ${ }^{\text {li }}$ As individuals explain their influence on politics through structured campaigns, Polana becomes increasingly incidental to how they imagine and experience themselves as part of a wider political community. Different ideas and exchanges appear central. For example, some emphasise how they helped to orchestrate the movement of voters from one area to another to influence election outcomes in a particular area, ${ }^{\text {lii }}$ while others recall how they were part of a physical confrontation at a polling station, helping to prevent an opponent from rigging ballot boxes. ${ }^{\text {lii }}$ Other participants explain how they individually worked to uphold official procedures through civic education and election monitoring.

Looking across participants' narratives of their political influence, they diverge in which actions and relations they emphasise. Some relate to authority and each other through public debate; places such as Polana are the epicentre of how they form and influence public relations. For others, public debate is of secondary importance compared to the influence derived through direct, more coercive and strategic involvement in election campaigns, as a strategist shaping outcomes or as an aspirant to elective office themselves. Participation through Polana is integrated into multiple ways of imagining oneself as part of a wider public. Polana can be an expression of citizenship. Its debate is imagined as a particular form of democracy. Polana can be seen as a way to educate and inform. Here, its debate is imagined to create informed citizens. Further, Polana can be a means to manipulate public opinion to further particular interests, and its debate becomes a frontier for the contest for 


\section{S. Diepeveen}

authority. Multiple interpretations of Polana reveal uncertainty and diversity in how it informs participants' understandings of themselves as part of a wider community.

\section{Public discussion during election campaigns}

Demonstrations of force and violence can overwhelm the presence of unpredictability of public discussion at Polana. In practice, Arendt suggests public discussion does not necessarily escape the world of violence, but can emerge through even the fictions of a totalitarian dictatorship. ${ }^{\text {lv }}$ Indications of violence and force are evident in the nature of the place, ideas and imaginaries that constitute Polana. For example, physical violence disrupts the gathering, and people's imaginings of the gathering are shaped by competition over forms of authority. During election campaigns, Polana becomes subsumed by electoral contests that are perceived to operate by a means-end logic, and to involve licit and illicit strategies to influence its outcome. Participants consistently describe elections in Mombasa as a high stakes contest, which not only revolves around voters' interests and choices, but also is driven by elite interests, and unfolds through well-resourced and underhanded campaign

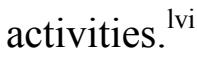

Election campaigns transform Polana by redirecting participants' interests and by reshaping the gathering itself. As they relay stories of the past elections, individuals from Polana situate themselves within personal and strategic campaigns. Their integration into the campaigns takes different forms, with participants identifying as aspirants, campaigners and campaign strategists, and civic educators and polling agents. Polana as a gathering is also transformed in the context of the election campaigns. Interviewees recall it as having grown in size and dynamism during the campaigns. Political agents, campaigners and aspirants pass by in increasing numbers throughout the electoral season. Frontrunner gubernatorial, senatorial and women's representative candidates in Mombasa attended Polana in the months preceding the 2013 General Elections. ${ }^{\text {lvii }}$ Aspirants use the gathering to publicise their 
campaigns. When a politician comes, a few interviewees from Polana allege that people flock to the gathering with the hope of an immediate financial handout. lviii

While electoral competition infiltrates discussion during election campaigns, Polana does not fully lose its potential as a free and open public. It remains a place to understand and shape public understanding through speech, preserved through the publicity of the street. The engagement of political leaders and aspirants in public dialogue at Polana suggests they perceive something about the gathering is significant to their interests. One male participant commented, "If there was not an impact they would not waste their time.",lix The intangible nature of the gathering motivates political aspirants' participation. Participants at Polana are imagined to represent wider opinions and dialogue throughout the county. Some politicians perceived them to be "opinion formers," who influence wider public opinion by voicing ideas shared at the gathering more widely in Mombasa. Politicians are also expected to partake in an informed and reasoned discussion. Electoral competition might feature strongly in the composition and content of discussion at the street parliaments, but its transformation of the gatherings is partial and temporary. As Election Day passes, campaigns and their effects subside. As people return to more mundane routines post election, the intensity of debate and political leaders' interest lessen.

\section{Conclusion}

Through the form and dynamism of the place, ideas or people that constitute Polana, the gathering reveals constrained conditions for an informal and open debate. Since the mid1990s, Polana has been a daily gathering of individuals who are interested in accessing and debating information about Kenyan politics. Ideas and people come and go, with various claims being made as to their validity. Movement and uncertainty of who is present indicates publicity and individual freedom over appearances within the exchange. Yet, this open debate 


\section{S. Diepeveen}

is constrained. Tensions over language, partisan politics and ethnicity emerge through debate at Polana. The absence of women, for example, from the space reveals exclusionary dimensions. Polana's existence as a space for open public discussion is also contingent upon the places and times that people are unoccupied by work and responsibilities in the home, and the possibilities of its discussion are tenuous. The ideas that are shared are refutable, and the gathering itself is compromised by the presence of violence and electoral competition.

Polana does not appear to be unique in Kenya in its constrained opportunities for public discussion. Research on street parliaments elsewhere in Kenya reveals similar opportunities for open and impersonal discussion. Bunge in Eldoret and Nairobi emerge as sites of informal public discussion, while also reflecting national tensions and forms of exclusion in varying ways. ${ }^{1 \mathrm{x}}$ With this in mind, the case of Polana indicates the possibility for unpredictability in a common public world through instances of informal discussion in Kenya. Even when deeply entangled with contests for authority during elections, Polana retains the possibility for plural and public dialogue. The possibility for new and shared imaginaries through Polana appears to be suspended between conditions of predictability and uncertainty. There is a degree of predictability to the gathering, in where it materialises, how people engage and how they are recognised. This consistency suggests an identity for the gathering, and indicates a common basis of understanding from which people can speak and make sense of the interactions. Polana is also uncertain; its form, participants and discussion are always changing. Uncertainty provides scope for participants to imagine Polana in different ways, while routine helps to enable and sustain public dialogue.

As it stands, Polana provides for multiple, conflicting and tenuous shared imaginaries. Beyond this, its activity and unpredictability indicate wider possibilities for new and shared imaginaries in Kenya that are bound to the persistence of public discussion. Polana reveals an ongoing interest amongst its participants in engaging in public discussion. They choose to 
informally and voluntarily convene in their leisure time. It also suggests the irrepressibility of the potential for changes to shared imaginaries, tied to the unpredictability of public speech and action. Indications of the potential for a new and different "common world" have remained through the bunge's ongoing public discussion, and amidst competing interests and forms of insecurity. 


\section{Acknowledgements}

The author would like to thank the numerous people at bunge throughout Mombasa, as well as in civil society and the County Assembly, who participated in this research with continued receptiveness and interest.

\section{Funding}

This work was supported by the Social Sciences and Humanities Research Council (Canada); the Smuts Memorial Fund; the Department of Politics and International Studies (Cambridge); and Jesus College, Cambridge.

\section{Disclosure statement}

No potential conflict of interest was reported by the author.

\section{Notes}

i Banégas et al., "Espaces publics de la parole”; Brisset-Foucault, "A Citizenship of Distinction”; and Rasmussen and Omanga, "Les Parlements Du Peuple."

${ }^{\text {ii }}$ See Barber, Readings; Dolby, "Popular Culture"; Ellis, "Pavement Radio"; Ogola, "Popular Culture and Politics"; Ogola, "Political Economy of the Media"; and Willems, "Public Sphere and Popular Culture.”

iii See Agovi, "Ghanaian Highlife Songs"; Collins, "Ghanaian Popular Performance”; Sekoni, "Politics and Urban Folklore"; and Van der Geest and Asante-Darko, "Highlife Songs in Ghana."

iv Ellis, "Pavement Radio"; and Ellis, "Rumour and Power."

v See, for instance, Bosch, "Talk Radio"; and Brisset-Foucault, “A Citizenship of Distinction."

vi Osborn, "Fuelling the Flames."

vii Banégas et al., "Espaces publics de la parole"; and Rasmussen and Omanga, "Les Parlements Du Peuple."

viii Habermas, "Structural Transformation."

${ }^{\text {ix }}$ See Barro, "Trans-nationalizing the African Public Sphere"; and Mustapha, "The Public Sphere."

${ }^{x}$ Villa, The Cambridge Companion.

${ }^{\mathrm{xi}}$ Arendt, The Human Condition, 200. 
xii Arendt, The Promise of Politics, 106.

xiii Ibid., 100.

${ }^{\text {xiv }}$ Ibid., 148.

${ }^{x v}$ Eisenberg, "Hip-hop and Cultural Citizenship."

xvi Loimeier, "Baraza in Zanzibar," 188.

xvii Kresse, Philiosophising in Mombasa.

xvii Swartz, The Way the World is.

${ }^{\text {xix }}$ Kresse, Philiosophising in Mombasa.

${ }^{\mathrm{xx}}$ Haugerud, Politics in Modern Kenya.

xxi Eisenberg, "Islam, Sound and Space," 190.

xxii Wolf, et al., "Kenya Coast Survey."

xxiii Eisenberg, "Hip-hop and Cultural Citizenship."

${ }^{x x i v}$ In the central business district (CBD), I was referred to bunge near the post office, towards Majengo, in front of the Splendid hotel building, and outside the Polana hotel building. I was also directed to numerous bunge outside of the $\mathrm{CBD}$, usually near a matatu (minibus) stage, school yard or on the road side, including: two in Likoni constituency, near the ferry and in Mtongwe; at Bomu primary schoolyard and at Kwa Hola on Airport Road in Magongo; at VOK, Lights and Kiembeni in Kisauni constituency; and in Maweni, Kongowea (Karama stage) and Mkomani in Nyali constitueney.

${ }^{\mathrm{xxv}}$ Kimari and Rasmussen, "Setting the Agenda"; Olagoke, "Framing Rights - Building Democracy"; Rasmussen, "Spreading the Word"; and Rasmussen and Omanga, "Les Parlements Du Peuple." xxvi Anderson and McKnight, "Kenya at war"; and Horowitiz and MUHURI, "Taking You to the Court."

xxvii For convenience purposes the author uses the name "Polana" to refer to this gathering in this paper.

xxviii Rasmussen and Omanga, "Les Parlements Du Peuple."

xxix Interview, 1 March 2014.

xxx Interview, 14 March 2014.

xxxi Interviews with male participants from Polana on 23 January 2014, 25 February 2014, 27 February 2014 and 13 March 2013.

xxxii Dynamics in bunge la mwananchi in Eldoret have also been noted to reflect ethnic coalition building in national politic. See Rasmussen and Omanga, "Les Parlements Du Peuple."

xxxiii Interview, 25 February 2014.

xxxiv During fieldwork, the label "psychofans" was used to describe individuals who actively and publicly advocate for a particular party or politician, and refuse to acknowledge any fault of their chosen candidate. 
${ }^{\mathrm{xxxv}}$ The press conference was reported as occurring around 2pm. See Mosoku, "Raila Odinga moves." xxxvi Ongiri, "Former PM to remain"; and Mosoku, "Raila Odinga moves."

xxxvii Interview, 9 April 2014.

xxxviii Interview, 7 April 2014.

xxxix Interviews with participants from Polana on 23 January 2014, 13 March 2014 and 17 March 2014.

${ }^{x l}$ Rasmussen and Omanga, "Les Parlements Du Peuple."

${ }^{x l i}$ Interviews with male participants from Polana on 22 February 2014, 28 February 2014, 3 March 2014, 13 March 2014, 17 March 2014, 18 March 2014 and 27 March 2014.

xlii Interview, 27 February 2014.

xliii Interview, 28 February 2014.

xliv Interviews with male participants from Polana on 29 January 2014, 26 February 2014, 5 March 2014, 6 March 2014 and 17 March 2014.

xlv Interview, 5 March 2014.

xlvi Ibid.

xlvii Interview with a Luo mzee from Polana on 10 March 2014.

xlviii Interviews with male participants from Polana on 5 February 2014, 26 February 2014, 17 March 2014 and 27 March 2014.

xlix Interviews with male participants from Polana on 27 February 2014, 28 February 2014 and 6 March 2014.

${ }^{1}$ Interviews with male participants from Polana on 28 February 2014, 5 March 2014, 6 March 2014, 10 March 2014, 12 March 2014, 13 March 2014, 14 March 2014 and 17 March 2014.

${ }^{l i}$ Five interviewees from Polana openly discussed contesting in past elections (either primaries or the General Elections). Interviews with male participants from Polana on 29 January 2014, 22 February 2014, 26 February 2014, 4 March 2014 and 28 March 2014.

${ }^{\text {lii }}$ Interviews with campaign coordinators and voters passing through Polana and other bunge on 8 January 2014, 29 January 2014, 1 April 2014 and 9 April 2014.

liii Interviews with campaigners from Polana on 3 March 2014 and 13 March 2014.

liv Interviews with civic educators from Polana on 25 January 2014 and 1 March 2014.

"v Arendt, "Totalitarian Imperialism," 6.

lvi Interviews with male participants from Polana on 27 February 2014, 3 March 2014 and 3 April 2014.

lvii Interviewees mentioned the following politicians' visits to Polana in the lead-up to the March 2013 elections, among others: Suleiman Shahbal (Wiper Democratic Movement, gubernatorial aspirant), Hassan Ali Joho (ODM, gubernatorial aspirant), Hebron Awiti Bollo (Wiper Democratic Movement, MP aspirant), Abdulswamad Shariff Nassir (ODM, MP aspirant), Hassan Omar Hassan (Wiper Democratic Movement, senatorial aspirant), Ramadhan Seif 
Kajembe (ODM, senatorial aspirant), Najib Balala (The Republican Congress, senatorial aspirant), Mishi Mboko (ODM, Women's representative aspirant), Margaret Olang (Ford Kenya, Women's representative aspirant).

Iviii Interviews with male participants from Polana on 23 January 2014, 10 March 2014 and 17 March 2014. Also personal correspondence with male participants from Polana on 22 February 2014, 11 March 2014 and 18 September 2014.

lix Interview, 1 March 2014.

${ }^{1 x}$ Rasmussen and Omanga, "Les Parlements Du Peuple."

\section{Bibliography}

Agovi, Kofi E. “The Political Relevance of Ghanaian Highlife Songs Since 1957.” Research in African Literatures 20, no. 2 (1989): 194-201.

Anderson, David, and Jacob McKnight. "Kenya at war: Al-Shabaab and its enemies in Eastern Africa." African Affairs 114, no. 454 (2015): 1-27.

Arendt, Hannah. The Human Condition. London: University of Chicago Press, 1958.

Arendt, Hannah. The Promise of Politics, edited by Jerome Kohn. New York: Random House, 2005.

Arendt, Hannah. "Totalitarian Imperialism: Reflections on the Hungarian Revolution.” The Journal of Politics 20, no. 1 (1958): 5-43.

Banégas, Richard, Brisset-Foucault, Florence, and Armando Cutolo. "Espaces publics de la parole et pratiques de la citoyenneté en Afrique.” Politique Africaine, no. 127 (2012): 5-20.

Barber, Karin, (ed.) Readings in African Popular Culture. Oxford: James Currey, 1997.

Bosch, Tanja. "Talk radio, democracy and citizenship in (South) Africa." In Popular Media, Democracy and Development in Africa, edited by Herman Wasserman, 75-87.

London: Routledge, 2010.

Brisset-Foucault, Florence. "A Citizenship of Distinction in the Open Radio Debates of Kampala." Africa 83, no. 2 (2013): 227-50.

Barro, Maimouna. "Trans-nationalizing the African Public Sphere: What Role for Transborder Languages?" Africa Development 35 no. 1-2 (2010): 55-70.

Collins, John. "Ghanaian Popular Performance and the Urbanisation Process: 1900-1980." Transactions of the Historical Society of Ghana, no. 8 (2004): 203-26. 
Dolby, Nadine. "Popular Culture and Public Space in Africa: the Possibilities of Cultural Citizenship." African Studies Review 49, no. 3 (2006): 31-47.

Eisenberg, Andrew J. "Hip-hop and Cultural Citizenship on Kenya's 'Swahili Coast'." Africa 82, no. 4 (2012): 556-78.

Eisenberg, Andrew J. "Islam, Sound and Space: Acoustemology and Muslim Citizenship on the Kenyan Coast." In Music, Sound and Space: Transformations of Public and Private Experience, edited by Georgina Born, 186-202. Cambridge: Cambridge University Press, 2013.

Ellis, Stephen. “Tuning in to Pavement Radio.” African Affairs 88, no. 352 (1989): 321-30.

Ellis, Stephen. "Rumour and Power in Togo." Africa 63, no. 4 (1993): 462-76.

Haugerud, Angelique. The Culture of Politics in Modern Kenya. Cambridge: Cambridge University Press, 1995.

Horowitiz, Jonathan, and Muslims for Human Rights (MUHURI). “'We're Tired of Taking You to the Court': Human Rights Abuses by Kenya's Anti-Terrorism Police Unit." New York: Open Society Justice Initiative and Muhuri, 2013.

Kimari, Wangui, and Jacob Rasmussen. "'Setting the Agenda for Our Leaders From Under a Tree': The People's Parliament in Nairobi." Nokoko (2010): 131-59.

Kresse, Kai. Philosophising in Mombasa: Knowledge, Islam and Intellectual Practice on the Swahili Coast. Edinburgh: Edinburgh University Press, 2007.

Loimeier, Roman. "Baraza as Markers of Time in Zanzibar." In Knowledge, Renewal and Religion: Repositioning and Changing Ideological and Material Circumstances Among the Swahili on the East African Coast, edited by Kjersti Larsen, 177-97. Uppsala: Nordiska Afrikainstitutet, 2009.

Mosoku, Geoffrey. 2014. "Raila Odinga moves to forestall party fallout," The Standard Digital, March 3. Accessed March 4, 2014. http://www.standardmedia.co.ke/?articleID=2000106025\&story_title=raila-moves-toforestall-party-fallout

Mustapha, Abdul Raufu. "The Public Sphere in 21st Century Africa: Broadening the Horizons of Democratisation." Africa Development 37, no. 1 (2012): 27-41.

Ogola, George. 'Popular Culture and Politics: Whispers and the 'dramaturgy of power' in Kenya." Social Identities 11, no. 2 (2005): 147-60. 
Ogola, George. "The Political Economy of the Media in Kenya: From Kenyatta's Nationbuilding Press to Kibaki's Local-language Fm Radio.” Africa Today 57, no. 3 (2011): 77-95.

Olagoke, Simone Ibiyemi. "Framing Rights - Building Democracy: A Case Study of the Social Movement Bunge La Mwananchi Political Practice as a Strategy for Developing a Radical and Relevant Democracy.” Masters thesis, Roskilde University, 2014.

Ongiri, Isaac. 2014. "Former PM to remain party leader and will work with both teams." Daily Nation, March 3. Aaccessed March 4, 2014.

http://www.nation.co.ke/news/politics/-/1064/2229576/-/xibymy/-/index.html

Osborn, Michelle. "Fuelling the flames: Rumour and Politics in Kibera." Journal of Eastern African Studies 2, no. 2 (2008): 315-27.

Rasmussen, Jacob. "Spreading the Word: The Public Oral Debate of the People's Parliament in Nairobi." Paper presented at the AEGIS, Uppsala, 2011.

Rasmussen, Jacob, and Duncan Omanga. "Les Parlements Du Peuple Au Kenya: Débat Public Et Participation Politique À Eldoret Et Nairobi.” Politique Africaine no. 127 (2012): 71-90.

Sekoni, Ropo. "Politics and Urban Folklore in Nigeria." In Readings in African Popular Culture, edited by Karin Barber, 142-46. Oxford: James Currey, 1997.

Swartz, Marc J. The Way the World is: Cultural Processes and Social Relations Among the Mombasa Swahili. Berkeley, CA: University of California Press, 1991.

Van der Geest, Sjaak, and Nimrod K. Asante-Darko, “The Political Meaning of Highlife Songs in Ghana." African Studies Review 25, no. 1 (1982): 27-35.

Villa, Dana. The Cambridge Companion to Hannah Arendt. Cambridge: Cambridge University Press, 2000.

Willems, Wendy. "Interrogating Public Sphere and Popular Culture as Theoretical Concepts on Their Value in African Studies." Africa Development 37, no. 1 (2012): 11-26.

Wolf, Tom, Muthoka, Samuel, and Margaret Ireri. "Kenya Coast Survey: Development, Marginalization, Security and Participation.” Nairobi: Ipsos Public Affairs, October 2013. 